\title{
Introduction: Objects, Circuits, and Southeastern Europe
}

\author{
Michat Wasiucionek \\ New Europe College (LuxFaSS) / Nicolae Iorga Institute of History, \\ Bucharest, Romania \\ michal.wasiucionek@eui.eu
}

\begin{abstract}
The scope of the paper is to provide the overview of the methodological developments that contributed to the growing interest in the nexus of material culture, circulation, and social networks, as well as the place of early modern Southeastern Europe, within the wider historiographical trends. To this end, it examines the very notion of Southeastern Europe and its impact on historical research in the region, while also providing a short discussion of the studies included in the issue.
\end{abstract}

\section{Keywords}

Southeastern Europe - consumption - early modern period - metageography

\section{Introduction}

In the first half of the eighteenth century, a boyar and historian Ion Neculce wrote down an apocryphal story about Moldavians' first contact with coffee. According to him, this took place as early as the 1510s, when Chancellor Ion Tăutu arrived at the Sublime Porte to accept the sultan's suzerainty over the country. Unfamiliar with Ottoman etiquette, Tăutu was confused when the courtiers removed his shoes and seated him on a carpet to dine with the grand vizier. After the coffee was served, the boyar, unsure how to proceed and anxious not to slight his host, offered a toast "Long live the sultan and the grand 
vizier!" and poured the whole cup of hot beverage down his throat, burning himself in the process. ${ }^{1}$

The story is without a doubt a fanciful invention by Neculce or one of his oral sources, since Tăutu's mission predated the arrival of coffee to the imperial capital by several decades. ${ }^{2}$ However, while writing down the amusing anecdote, the Moldavian chronicle did not have to explain to his audience what Tăutu had done wrong, coffee-wise. By the eighteenth century, the Moldavian elite had accommodated the beverage and developed the vibrant coffee culture, similar to that across the Ottoman space. ${ }^{3}$ The taste for the beverage and another new substance- tobacco-had a tremendous impact on the inhabitants of the sultan's "Well-Protected Domains." The mushrooming of coffeehouses reshaped the topography of everyday life, creating new types of public spaces where individuals from different walks of life and social status met, mingled, and forged new identities and patterns of behavior. ${ }^{4}$ At the top of the social hierarchy, servants responsible for brewing coffee and handling tobacco became a fixture in the households of Ottoman officials, notables, and Christian hierarchs. ${ }^{5}$ As Cemal Kafadar pointed out, in the mid-seventeenth century, coffee "constituted a boundary marker as a popular item of consumption that was a distinctive characteristic of the Ottoman world." ${ }^{6}$ This process of adoption was by no means smooth or uncontroversial. On the contrary, while the allure of leisurely activities offered by the new venues attracted

1 Ion Neculce, Opere: Letopisețul Țării Moldovei și O samă de cuvinte [Chronicle of Moldavia and A Couple of Stories], ed. Gheorghe Ștrempel (Bucharest, 1982), 168-169.

2 Ayşe Saraçgil, "L'introduction du café à Istanbul (XVI tés, eds. Hélène Desmet-Grégoire and François Georgeon (Paris, 1997), 25-38.

3 Ralph S. Hattox, Coffee and Coffeehouses: The Origins of a Social Beverage in the Medieval Near East (Seattle, 1998); Ali Çaksu, "Janissary Coffee Houses in Late Eighteenth-Century Istanbul," in Ottoman Tulips, Ottoman Coffee: Leisure and Lifestyle in the Eighteenth Century, ed. Dana Sajdi (London, 2003), 117-132; Alan Mikhail, "The Heart's Desire: Gender, Urban Space and the Ottoman Coffee House," in Sajdi, Ottoman Tulips, Ottoman Coffee, 133-170. On the Southeastern European perspective, see: Constanța Vintilă-Ghițulescu, Evgheniți, ciocoi, mojici: despre obrazele primei modernități românești, 1750-1860 [The Well-Born, Boyars, Plebeians: On the Facets of Romanian First Modernity, 1750-186o] (Bucharest, 2013), 130; Aleksandar Fotić, "The Introduction of Coffee and Tobacco to the Mid-West Balkans," Acta Orientalia Academiae Scientiarum Hungaricae 64, no. 1 (2011): 89-10o.

4 Cemal Kafadar, "How Dark is the History of the Night, How Black the Story of Coffee, How Bitter the Tale of Love: The Changing Measure of Leisure and Pleasure in Early Modern Istanbul," in Medieval and Early Modern Performance in the Eastern Mediterranean, eds. Aksu Öztürkmen and Evelyn Birge Vitz (Turnhout, 2014), 244.

5 Fotić, "The Introduction of Coffee," 94.

6 Cemal Kafadar, "Evliya Çelebi in Dalmatia: An Ottoman Traveler's Encounter with the Arts of the Franks," in Dalmatia and the Mediterranean: Portable Archeology and the Poetics of Influence, ed. Alina Payne (Leiden, 2014), 68. 
many, it also created anxiety about the subversion of the established order, moral decline, and religious transgression. ${ }^{7}$ The polemics over the legality and admissibility of coffee and tobacco cut across confessional boundaries, involving both Muslim and Christian authors. ${ }^{8}$ In their turn, political authorities in Istanbul, Bucharest, and Iași were deeply concerned about the potential of public unrest the coffeehouses posed, prompting them to repeatedly shutter all coffeehouses, but to no avail. Nonetheless, coffee culture remained one of the elements of Ottoman heritage across Southeastern Europe and the Eastern Mediterranean, with "Turkish coffee" remaining arguably the most popular hot beverage until this day except for, ironically, in Turkey itself. The link between the Ottoman polity and coffee consumption was also construed by the contemporaries; it is not an accident that Neculce's account tied Moldavians' encounter with coffee with the mission, which, according to the tradition, marked the principality's entry under Ottoman suzerainty.

The success story of coffee's introduction and adoption throughout the region, however, transcended the territorial reach of the sultans' domains, acquiring a global dimension. It was enabled by the Ottoman expansion in the Red Sea and into the Indian Ocean, undertaken in the aftermath of the conquest of the Mamluk Sultanate and pursued in competition with the Portuguese. ${ }^{9}$ The establishment of Ottoman control in Yemen provided a powerful impulse for the development of coffee production and trade, establishing commercial links between highland areas and Red Sea entrepots. ${ }^{10}$ However, by the seventeenth century, the province had already slipped from under imperial rule; nonetheless, trade continued, driven by Ottoman demand and encouraged by Qasimi rulers. ${ }^{11}$ As a result, before making its way into the cup in Bucharest, beans had

See Kafadar, "How Dark is the History of the Night," 249; James Grehan, "Smoking and 'Early Modern' Sociability: The Great Tobacco Debate in the Ottoman Middle East," American Historical Review 111, no. 5 (2006): 1352-1377. Evgenia Kermeli, "The Tobacco Controversy in Early Modern Christian and Muslim Discourse," Hacattepe Üniversitesi Türkiyat Araştırmaları 21 (2014): 121-135.

9 For an account of this expansion, see Giancarlo Casale, The Ottoman Age of Exploration (Oxford, 2010).

10 Suraiya Faroqhi, "Coffee and Spices: Official Ottoman Reactions to Egyptian Trade in the Later Sixteenth Century," Wiener Zeitschrift für die Kunde des Morgenlandes 76 (1986): 8892; Jane Hathaway, "The Ottomans and the Yemeni Coffee Trade," Oriente Moderno 25, no. 1 (2006): 161-171; Michel Tuscherer, "Coffee in the Red Sea Area from the Sixteenth to the Nineteenth Century," in The Global Coffee Economy in Africa, Asia and Latin America, 1500-1989, eds. Gervase Clarence-Smith and Steven Topik (New York, 2003), 51-52.

11 For a recent account of Red Sea coffee trade from a Yemeni perspective, see Nancy Um, Shipped but Not Sold:Material Culture and Social Protocols of Trade during the Yemen's Age of Coffee (Honolulu, 2017). 
to cross vast distances and pass through numerous hands, including those of Yemeni mountain tribes, traders from Jeddah, Egyptian janissaries, and Armenian merchants who controlled coffee trade in the principalities. It was only in the second half of the eighteenth century that this global flow of trade entered into decline, as the Eastern Mediterranean was swamped by cheaper beans originating from the French Caribbean, an even more expansive circuit of global trade. From this point of view, a cup of coffee consumed in Bucharest was by no means a local affair, but rather a case of convergence between the local and the global, in which local communities and cultural practices converged with global flows, mediated through imperial structures and regional frameworks. ${ }^{12}$

While no paper collected in this special issue addresses coffee consumption as its central topic, its story as a global commodity and as a popular beverage in the region perfectly captures the main themes the contributors seek to explore. The early modern period experienced an unprecedented growth of human mobility and circulation of goods that posed challenges for established orders, while at the same time providing new opportunities. Tangible objects in this context were not "a passive, inert material to which things happen and things are done," but rather an integral part of social action that produced both new meanings and patterns of behavior. ${ }^{13}$ Just as human actors produced, transported, consumed, and attached meaning to tangible things, the latter shaped conceptual and social frameworks, creating new modes of interaction, interpretation, and practice. Hence, rather than seeing objects and commodities as mere props, it is preferable to interpret their relationship with human actors as one of mutual definition, whereby the former ascribed meaning and function to the latter, while tangible objects in turn displayed the social identity of their owner. These encounters, however, would be incomprehensible without taking

12 For the concept of "localization of globality," see Ronald Robertson, "Mapping the Global Condition: Globalization as the Central Concept," Theory Culture and Society 7, no. 3-4 (1990): 19; Bartolomé Yun Casalilla, "Localism,' Global History and Transnational History: A Reflection from the Historian of Early Modern Europe," Historisk Tidskrift 127, no. 4 (2007): 669. I find this term preferable to the concept of "indigenization of modernity" proposed by Marshall Sahlins, "Goodbye to Tristes Tropes: Ethnography in the Context of the Modern World History," Journal of Modern History 65, no. 1 (1993): 1-25. As its critics point out, the latter concept carries diffusionist undertones, which presume the existence of a singular, homogenous and essentially European modernity, see Charles R. Cobb and Diana DiPaolo Loren, "The Earth of the Modern," Archaeologies: Journal of the World Archaeological Congress 4, no. 1 (2008): 14.

13 Chris Gosden and Yvonne Marshall, "The Cultural Biography of Objects," World Archaeology 31, no. 2 (1999): 169-170. See also, Arjun Appadurai, "Introduction: Commodities and the Politics of Value," in The Social Life of Things: Commodities in Cultural Perspective, ed. Arjun Appadurai (Cambridge, 1988), 1-64. 
into consideration the social and spatial framework within which they unfolded: individual interactions and acts of identification and self-fashioning would be incomprehensible without taking into consideration the regional, imperial, and global frameworks that enabled them in the first place. As the papers collected in the special issue demonstrate, combining the focus on the humans' engagement with objects and placing them within nesting spatial and social contexts opens new research vistas and allows for transcending beyond the established dichotomies of premodernity/modernity, local/global, and East/ West, which continue to shape the historical narratives of the region. As the papers in this volume seek to prove, such encounters between objects and people at the interface of local communities and global networks characterized the early modern period in Southeastern Europe.

The latter concept requires some unpacking, since few parts of the world have been subjected to constant political and discursive rearrangements and competing metageographies. ${ }^{14}$ None of the polities present in the region in the early modern period exist anymore, shattered into pieces or dissolved within larger nation-states. Modern historiographies picked up the shards and remolded them according to new principles and ideological imperatives. Obviously, the most controversial notion has been that of "the Balkans"; inspired by the analysis of orientalism and initiated by Maria Todorova's path-breaking book, the scholarship has been focused on the deconstruction of the region and mechanisms of mental mapping embedded in the public discourse and dessentializing the notion of the Balkans as Europe's "Other within."15 The symbolic and political charge associated with the term led both scholars and public figures to refrain from the term and search for alternatives. However, a seemingly

\footnotetext{
14 For the concept of metageographies and its contested character regarding Southeastern Europe, see Martin W. Lewis and Kären Wigen, The Myth of Continents: A Critique of Metageography (Los Angeles, 1997), esp. 65-67.

15 Maria Todorova, Imagining the Balkans, second ed. (Princeton, 2009); K.E. Fleming, "Orientalism, the Balkans, and Balkan Historiography," American Historical Review 105, no. 4 (2000): 1218-1233; Hans Sundhaussen, "Europa balcanica: Der Balkan als historischer Raum Europas," Geschichte und Gesellschaft 25, no. 4 (1999): 626-653; Maria Todorova, "Der Balkan als Analysekategorie: Grenzen, Raum, Zeit," Geschichte und Gesellschaft 28, no. 3 (2002): 470-492; Hans Sundhaussen, "Der Balkan: Ein Plädoyer für Differenz," Geschichte und Gesellschaft 29, no. 4 (2002): 608-624; Beyond the Balkans: Towards an Inclusive History of Southeastern Europe, ed. Sabine Rutar (Vienna, 2014). For a discussion of the debate, focusing on German academia, see Dietmar Müller, "Southeastern Europe as a Historical Meso-Region: Constructing Space in the Twentieth-Century German Historiography," European Review of History 10, no. 2 (2003): 393-408. A fresh look on the debate has been recently proposed by Diana Mishkova, who focuses on scholarly conceptualizations of the Balkans from within the region, see Diana Mishkova, Beyond Balkanism: The Scholarly Politics of Region Making (London, 2018).
} 
value-neutral alternative-that of Southeastern Europe-creates problems of its own. On the one hand, despite its claim to objectivity, its origins and usage have been just as embedded in scholarly and political agendas. ${ }^{16}$ There are also justifiable doubts regarding the "way of seeing" the notion imposes. As Alexander Vezenkov pointed out, the notion privileges continental divisions over historical experience, artificially divorcing what had been known as "European Turkey" from its Anatolian twin and providing a historical justification for inherent and essentialized "Europeanness" of the region throughout history ${ }^{17}$ Finally, applying the notion to the early modern period is admittedly an anachronism, given that the concept of Southeastern Europe as a historical region was a nineteenth-century invention. ${ }^{18}$

These are legitimate concerns; however, the debate that Imagining the Balkans sparked has not only identified the layers of discourse associated with the region and mechanisms of mental mapping, but also led-particularly within German academia-to a more refined reflection on historical regions as a conceptual and methodological tool. As Stefan Troebst pointed out, these new optics require approaching "a historical meso-region not in an essentialist or even geodeterminist way, but as an artistic device and heuristic concept for comparative analysis," which does not conform to political boundaries and is embedded in "multiple geographies" and "spatial layers" (Raumschichten).${ }^{19}$ However, while useful, this reframing begs the question of

16 As Diana Mishkova points out, its most prominent proponent, Romanian historian Nicolae Iorga, saw it as a vehicle for advancing Romanian national interests in the region, Mishkova, Beyond Balkanism, 62. In the context of German academia, the association of Südostforschung with Nazi expansionist plans long haunted the discipline, while the debate over "balkanism" has discouraged some scholars from trying to define the region at all, see Müller, "Southeastern Europe," 397-40o and 406.

17 Alexander Vezenkov, "History against Geography: Should We Always Think of the Balkans as Part of Europe?," in Ottoman Legacies in the Contemporary Mediterranean: The Balkans and the Middle East Compared, eds. Eyal Ginio and Karl Kaser (Jerusalem, 2013): 59-78.

18 The term was first introduced by Austrian diplomat Johann Georg von Hahn in 1861, although — as Alex Drace-Francis pointed out-it had a prehistory going back to the early nineteenth century, see Alex Drace-Francis, "The Prehistory of the Neologism: 'South-Eastern Europe'," Balkanologie 3, no. 2 (1999): 117-127.

19 Stefan Troebst, "Introduction: What's in a Historical Region? A Teutonic Perspective," European Review of History 10, no. 2 (2003): 178. In this regard, the most representative is the concept of Nordosteuropa developed by Klaus Zernack, who explicitly stated that the choice of the name was meant to be chosen precisely for its artificiality to demonstrate its status as an analytical tool, see Klaus Zernack, Nordosteuropa: Skizzen und Beiträge zu einer Geschichte der Ostseeländer (Lüneburg, 1993), 7-8. For the problem of "multiple geographies," see Michael G. Müller and Cornelius Torp, "Conceptualising Transnational Spaces in History," European Review of History 16, no. 5 (2009): 6o9-617. Finally, there have been numerous contributions advancing the adoption of Reinhart Koselleck's concept 
the heuristic utility of early modern Southeastern Europe; in short, given the efflorescence of Mediterranean and Ottoman historiography in recent decades, why do we need Southeastern Europe?

Since its resurgence in the early 2ooos, the study of the Mediterranean has been at the cutting edge of research on cross-cultural and trans-imperial history. Contributions by such authors as Eric Dursteler, Molly Greene, and Natalie Rothman opened up new perspectives into the research of Mediterranean "bazaars and battlefields." 20 This robust scholarship did away with the notion of the region as divided by a fixed civilization boundary, instead focusing on encounters, coexistence and the constant renegotiations of rules of collective and individual identities, seen as "a bundle of shifting interactions" rather than fixed and homogeneous properties. ${ }^{21}$ The advances in the field are best epitomized by the concept of "trans-imperial subjects" proposed by Natalie Rothman as a way to grasp the interactive way individual actors straddled political and confessional boundaries, while at the same time they articulated and constructed the notions of difference. ${ }^{22}$ Objects have been integral to this paradigm, as the circulation of the works of art, luxuries, and staples is currently seen as crucial for the Mediterranean encounters. ${ }^{23}$

However, despite becoming a historiographical juggernaut and a generator of methodology, Mediterranean studies have inherent limitations. The very definition of its area of interest as the region centered around the Middle Sea imposes a distinct way of seeing that Alina Payne elegantly dubbed "a view

of Zeitschichten (temporal layers) to space, see Hagen Schulz-Forberg, "The Spatial and Temporal Layers of Global History: A Reflection on Global Conceptual History Through Expanding Reinhart Koselleck's Zeitschichten into Global Spaces," Historical Social Research 38, no. 3 (2013): 40-58; Diana Mishkova, "What is in Balkan History? Spaces and Scales in the Tradition of Southeast-European Studies," Southeastern Europe 34 (2010): 57-58.

20 Eric Dursteler, Venetians in Constantinople: Nation, Identity, and Coexistence in the Early Modern World (Baltimore, 2006); idem, Renegade Women: Gender, Identity and Boundaries in the Early Modern Mediterranean (Baltimore, 2011); E. Natalie Rothman, Brokering Empire: Trans-Imperial Subjects between Venice and Istanbul (Ithaca, 2012). For a survey of the field, see Eric Dursteler, "On Bazaars and Battlefields: Recent Scholarship on Mediterranean Cultural Contacts," Journal of Early Modern History 15, no. 5 (2011): 413-434.

21 Dursteler, Venetians in Constantinople, 18.

22 Rothman, Brokering Empire, 5.

23 The discussion focused on the role of the Mediterranean encounters on the Renaissance, see Lisa Jardine and Jerry Brotton, Global Interests: Renaissance Art between East and West (London, 2000); Jerry Brotton, The Renaissance Bazaar: From the Silk Road to Michelangelo (Oxford, 2003); Re-Orienting the Renaissance, ed. Gerald MacLean (Basingstoke, 2005); The Renaissance and the Ottoman World, eds. Anna Contadini and Claire Norton (Farnham, 2013). 
from the boat," privileging the "the view of the passer-by who does not stop to experience the hinterland" and emphasizes the vantage point of maritime travel, ports of call, and the littoral. ${ }^{24}$ Moreover, the discussion over cultural encounter predominantly focused on a specific maritime route, connecting Venice and the Ottoman capital of Istanbul. While this approach is justified both by the richness of Ottoman and Venetian archives, the role of this axis in the early modern period, and the amazing results it yielded, it is important to remember that not all encounters took place along this axis, and the metropoles by no means constituted the only loci of encounter. This is particularly important given that the insistence on relational and processual character of identity formation makes it incumbent to take account of the different social and spatial contexts where the interactions took place; as contributions to this volume demonstrate, many of those encounters took place with no sea in sight. To try to accommodate them within a unitary framework of the Mediterranean would be difficult, given the concern among scholars regarding the dilution of the field's "Mediterraneanness" and their calls to refocus on the sea itself. ${ }^{25}$ "A view from the boat" should thus be complemented by "a view from the land." ${ }^{26}$ As the enthusiastic reception of Noel Malcolm's recent study on trans-imperial networks has shown, the dialogue between Southeastern European and Mediterranean fields has the potential to provide just such a perspective. ${ }^{27}$

Defining early modern Southeastern Europe as a historical region makes it incumbent to address the field's relationship with the Ottoman Empire, both as a polity and as a field of study. Since the $198 \mathrm{os}$, Ottomanists have increasingly chipped away at the notions of Ottoman decline, which cast the empire after the reign of Sultan Süleyman as a diminished and increasingly dysfunctional

24 Alina Payne, "The Thin White Line: Palladio, White Cities and the Adriatic Imagination," in Dalmatia and the Mediterranean: Portable Archaeology and the Poetics of Influence, ed. Alina Payne (Leiden, 2014), 171.

25 On this topic, see David Abulafia, The Great Sea: A Human History of the Mediterranean (Oxford, 2011), xvii; Maria Fusaro, "After Braudel: A Reassessment of Mediterranean History between the Northern Invasion and the Caravane Maritime," in Trade and Cultural Exchange in the Early Modern Mediterranean: Braudel's Maritime Legacy, eds. Maria Fusaro, Colin Heywood and Mohamed S. Omri (London, 2010), 5-6.

26 See Suzanne Marchand, "The View from the Land: Austrian Art Historians and the Interpretation of Croatian Art," in Dalmatia and the Mediterranean: Portable Archaeology and the Poetics of Influence, ed. Alina Payne (Leiden, 2014), 21.

27 Noel Malcolm, Agents of Empire:Knights, Corsairs,Jesuits and Spies in the Sixteenth-Century Mediterranean World (Oxford, 2015). For an earlier case of such productive engagement, see Catherine Wendy Bracewell, The Uskoks of Senj: Piracy, Banditry, and Holy War in the Sixteenth-Century Adriatic (Ithaca, 1992). 
shadow of its former glory, incapable of change except under Western influence. However, once this paradigm had been "relegated to the horse-andbuggy era as something once believed but no longer credible," scholars brought attention to the longevity and internal dynamism of the empire and its society and revaluated previously underserved aspects of the imperial history. ${ }^{28} \mathrm{~A}$ common thread of this revisionist scholarship is the appreciation of internal developments rather than Western influence as the driving force of political, social and cultural change. This shift towards Ottoman dynamics has at the same time been strongly tied to wider interpretative and geographical frameworks, such as the Mediterranean, the "Greater Western World," or western Eurasia. ${ }^{29}$ This led to a heightened reflection on the "specificity, not freakishness" of the Ottoman imperial experience, while at the same time demonstrating its broader embeddedness in the "connected histories" of the early modern world.$^{30}$ The focus on the tangible objects, involving historians of art, architecture, and consumption, has played a considerable role in this process, becoming major interlocutors with students of Mediterranean and global history. ${ }^{31}$

28 Linda T. Darling, "Rethinking Europe and the Islamic World in the Age of Exploration," Journal of Early Modern History 2, no. 3 (1998): 246; Rifa'at Ali Abou-El-Haj, Formation of the Modern State: The Ottoman Empire, Sixteenth to Eighteenth Centuries (Albany, 1991); Jane Hathaway, "Problems of Periodization in Ottoman History: The Fifteenth through the Eighteenth Centuries," Turkish Studies Association Bulletin 20, no. 2 (1996): 25-31; Linda T. Darling, "Another Look at Periodization in Ottoman History," Turkish Studies Association Bulletin 26, no. 2 (2002): 19-28; Baki Tezcan, The Second Ottoman Empire: Political and Social Transformation in the Early Modern World (Cambridge, 2010). For surveys of the field, see Dana Sajdi, "Decline, Its Discontents and Ottoman Cultural History: By Way of Introduction," in Ottoman Tulips, Ottoman Coffee: Leisure and Lifestyle in the Eighteenth Century (London, 2003), 1-40; Alan Mikhail and Christine M. Philliou, "The Ottoman Empire and the Imperial Turn," Comparative Studies in Society and History 54, no. 4 (2012): 721-754.

29 Palmira Brummett, "Visions of the Mediterranean: A Classification," Journal of Medieval and Early Modern Studies 37, no. 1 (2007): 9-55; Daniel Goffman, The Ottoman Empire and Early Modern Europe (Cambridge, 2002).

$30 \quad$ Mikhail and Philliou, "The Ottoman Empire," 743.

31 In the field of architectural history, see especially Gülrü Necipoğlu, The Age of Sinan: Architectural Culture in the Ottoman Empire (London, 2011). In the field of history of consumption, the scholarship has advanced exponentially since the pioneering studies of Donald Quataert, "Clothing Laws, State, and Society in the Ottoman Empire, 17201829," International Journal of Middle East Studies 29, no. 3 (1997): 403-425; Consumption Studies and the History of the Ottoman Empire, 1550-1922, ed. Donald Quataert (Cambridge, 20oo). For recent contributions, see Hedda Reindl-Kiel, Leisure, Pleasure and Duty: The Daily Life of Silahdar Mustafa Pasha, Eminence Grise in the Final Years of Murad IV (16351640) (Berlin, 2016); "A Tulip Age Legend: Consumer Behavior and Material Culture in the Ottoman Empire, 1718-1730" (unpublished Ph.D. dissertation, State University of New York at Binghamton, 2009), as well as the contributions in the collected volume Living 
While the geographical overlap between Ottoman and Southeastern European historiographic traditions should have encouraged dialogue and cooperation, the long-standing paradigm of the "Turkish yoke" has long beset attempts at a productive dialogue. ${ }^{32}$ By insisting on the inherent "Europeanness" of the region and casting the Ottoman rule as a foreign occupation, the narrative converged with orientalist stereotypes, overlaying the spatial distinction between Europe and Asia with a temporal one of modern and premodern; the narrative goes, "the European-type achievements of the new nations [...] were blocked, altered, or annihilated by Ottoman domination." ${ }^{33}$ In effect, centuries of Ottoman rule would act as a time capsule, preserving the peoples of the region in a stasis until the period of "national revivals" would allow essentially medieval societies to rejoin the flow of history. ${ }^{34}$

This assessment has had a powerful impact on historians' approach to tangible objects of the past. By interpreting Western-style objects and patterns of consumption as natural and inherently modern developments, both nineteenth-century nation-builders and modern historians have relegated the Ottomanized forms of materiality as inherently backward, premodern, and alien to the region. For nineteenth-century nationalists and reformers, social change and new identity were to penetrate Southeastern Europeans through wardrobes, European etiquette, and fluency in French..$^{35}$ This vision of unidirectional progression from East to West, adopted by modern historiography, militated against approaching Ottoman influences on par with Western ones or even treating the former as a dynamic material culture in its own right. The discourse surrounding Ottoman-style objects reproduced that of Orientalism in general, blaming them for encouraging laziness and immobility, and even posing health risks to their users. ${ }^{36}$ In effect, scholars discussing the sartorial

the Good Life: Consumption in the Qing and Ottoman Empires of the Eighteenth Century (Leiden, 2016).

32 On the "Turkish yoke" model, see Dariusz Kołodziejczyk, "The 'Turkish Yoke' Revisited: The Ottoman Non-Muslim Subjects Between Loyalty, Alienation and Riot," Acta Poloniae Historica 93 (2006): 177-195.

33 Valentin Georgescu, "La terminologie; modernization et europanisation de l'Empire Ottoman et du Sud-Est de l'Europe à la lumière de l'expérience roumaine," in La revolution industrielle (Sofia, 1976), 120-121, after Mishkova, Beyond Balkanism, 162.

34 For the discussion of the concepts of "national revival" on the example of Bulgarian historiography, see Roumen Daskalov, The Making of a Nation in the Balkans: Historiography of the Bulgarian Revival (Budapest, 2004).

35 Alecu Russo, "Studie moldovană [A Moldavian Study]," in Alecu Russo, Scrieri, ed. Petre V. Haneş (Bucharest, 1934), 12.

36 Mirjana Prošić-Dvornić, "Pokušaji reformi odevanja u Srbiji tokom XIX i početkom XX veka" [Attempts at the Reform of Attire in Serbia in the Nineteenth and at the Beginning 
revolution that swept the region in the first half of the nineteenth century interpreted it as a deliberate rupture with the Ottoman past, ignoring the fact that the empire landscape was undergoing similar changes. ${ }^{37}$ The exception was made for material culture of the peasants, seen as a repository of preOttoman traditions and as such untouched by the "Turkish yoke."

As studies collected in this special issue demonstrate, such position is no longer tenable and a reconnection of the two strands of scholarship is urgently needed. As the collective evidence from these studies shows, studying circulations and interactions with objects across early modern Southeastern Europe provides an attractive approach to overcome established binaries. The materiality of tangible things and negotiations over their use and meaning cut across social and confessional lines and constituted loci of negotiation of collective and individual identities, while their circulation and consumption tied them to broader regional, trans-imperial, and trans-national networks. ${ }^{38}$ What emerges is a picture of a complex, multifocal region, whose cultural interactions were largely conditioned but not defined solely by the metropolitan material culture of Istanbul. In fact, although case studies presented in the issue unfolded primarily within Ottoman space, the contributions in this issue demonstrate the advantages of adopting a regional approach instead. By examining sources, sites, and actors that usually fall beyond the purview of Ottoman scholarship, they present an alternative and complementary vision of the region that humans and objects created: a polycentric region that-although integrated into the Ottoman Empire - was by no means defined solely by the influence of the imperial center and characterized by multiple entanglements, geographies, and encounters. In doing so, they undermine the homogenizing notions of "Ottoman" and "Western" models, instead placing individual trajectories at the crux of commercial, confessional, political, and cultural flows that crisscrossed the region, and emphasizing the role of individual agency in the process of human-object encounters and their multiple interpretations.

of the Twentieth Century] in Gradska kultura na Balkanu (XV-XIX vek): Zbornik radova, vol. 2, ed. Verena Han (Belgrade, 1988), 177-206.

37 For this topic, see for instance John P. Dunn, "Clothes to Kill For: Uniforms and Politics in Ottoman Armies," Journal of Middle East and Africa 2, no. 1 (2011): 85-107.

38 On the role of networks in the region and the wider Mediterranean and Eurasian worlds, see Francesca Trivellato, The Familiarity of Strangers: The Sephardic Diaspora, Livorno, and Cross-Cultural Trade in the Early Modern Period (New Haven, 20o9); Sebouh David Aslanian, From the Indian Ocean to the Mediterranean: The Global Trade Networks of Armenian Merchants from NewJulfa (Berkeley, 2011). For the use of term "trans-national" in the early modern context, see Yun Casalilla, "'Localism,' Global History and Transnational History," 667-668. See also the use of the term "natio/nation" in Trivellato, The Familiarity of Strangers, 43-44. 
The contributions to this volume do not claim to provide a comprehensive account of the changing material culture in Southeastern Europe and the Mediterranean, but rather examine capillary currents, which tied the region to broader networks of trade, politics, and intellectual life. While touching on different topics, they all embrace a "bottom-up" perspective, approaching individual flows of peoples, objects, and ideas through trans-imperial and transnational spaces throughout the early modern period. What emerges is not a homogenous unidirectional change, but rather a kaleidoscopic and intersectional landscape encompassing multiple geographies of flows, which elude the simple master narratives. Rather than provide a coherent new paradigm, the studies - most of which originated from a workshop held at the European University Institute in Florence in May 2017-invite us to rethink and recalibrate our assumptions regarding the history of Southeastern Europe through the lens of objects and the circuits that brought them into the region.

The first two contributions explore the complex role luxury objects played as markers of identity and status in diplomatic and political interactions. While high politics have long been at the center of scholarly interest in Southeastern Europe, the approach has remained conservative, focusing on geopolitics and balance of power rather than their cultural and social underpinnings. In contrast, the papers address the relationship between the elites and their selffashioning strategies, as mediated through the diplomats' attitude towards material objects.

In the first study, Michał Wasiucionek brings together material objects, narrative sources, and chancellery documents to reconstruct the strategies of selffashioning employed by the seventeenth-century Moldavian voyvode Ştefan Tomşa II. As the study argues, the claims of Tomşa's contemporaries, accusing him of "being a Turk" had nothing to do with his religion, but rather with his adoption of Ottoman attire and norms of behavior, nor was it a slander meant to discredit the voyvode. Despite remaining an Orthodox Christian throughout his life, Tomşa deliberately presented himself as a participant in the Ottoman imperial culture through his attire, political rhetoric, and even the usage of a tuğra-inspired monogram. While employed in the context of the particularly fraught reign of the voyvode, his subscription to Ottoman models represented a broader phenomenon of "Christian Ottomanization" in the Danubian principalities, with clear parallels among the Muslim elites across the empire.

In turn, Constanța Vintilă-Ghiţulescu explores the intricacies of eighteenthcentury cultural mediation and transimperial diplomacy through the eyes of Ianache Văcărescu. Văcărescu, a high-ranking Wallachian boyar and a man of letters, arrived at the Habsburg court in Vienna in 1782, entrusted with a sensitive task of bringing fugitive sons of the Wallachian voyvode back to the 
principality. Examining Văcărescu's account of the mission, the author investigates the nexus of luxury consumption, court civility, and social distinction, asking whether we can interpret the Wallachian boyar as a trans-imperial subject. In the process, she elucidates different meanings of civility and cultural boundaries shaping and constructing the diplomatic contact between the Ottoman cultural ecumene and the Habsburg court.

The following section shifts its focus to a different category of actors and flows, shedding light on the merchants and wares embedded in circuits of international commerce. In her contribution, Mária Pakucs employs sixteenth- and seventeenth-century customs registers and merchant ledgers from Transylvanian commercial hubs of Sibiu, Brașov, and Cluj to elucidate the main features of the towns' involvement in the trade in Ottoman textiles. As the author points out, while frequently neglected in wider discussions of Ottoman commercial ties with Europe, the Principality of Transylvania constituted not only an important route by way of which fabrics produced in the "well-protected domains" made their way into Central Europe, but was an important market in its own right. Challenging the established views regarding the types of Ottoman textiles sought in European markets, the paper emphasizes the role of relatively cheap, lighter fabrics in the commercial exchanges between Transylvania and the empire, as well as their impact on the sartorial landscape of the region.

In turn, David Celetti sets out from the depiction of Marseille trade by Claude-Joseph Vernet to discuss the impact of the port's trade with the Eastern Mediterranean in the eighteenth century and the intersecting circuits of commercial, diplomatic, and social relations that French commercial activity relied on. Exploring the consular correspondence of this period, he explores not only the role of French trade networks in bringing new commodities to the region and reshaping the Ottoman economy but also the role of Levantine échelles as loci, where divergent visions of the trading community clashed and complemented each other. Whereas French authorities pursued a vision of a distinctive and regulated mercantile community and tried to enforce administrative control and suppress internal competition, the merchants offered a different vision, demanding a more flexible system, fewer regulations, and more porous boundaries. In effect, consuls tasked with enforcing new rules found themselves in the crossfire, forced to mediate between these competing agendas. In the end, it was the consuls' skillful management of contradictory pressures at the interface of the trading community and state authorities that allowed French commerce in the Levant to thrive throughout the eighteenth century.

In her contribution, Artemis Yagou examines the very notion of luxury objects, analyzing a group of trefoil ceramic jugs produced in Pesaro for the 
Epirote market in the second half of the eighteenth century. While pedestrian objects in quality and craftsmanship, they can be interpreted as "popular luxuries," embedded in the interactive process of their commissioning and customization. For the newly assertive merchant class of Ioannina and Kalarrytes, adorning the jugs with moralistic or satirical inscriptions in Greek verse offered an opportunity to exercise their agency as customers, transforming the objects from undifferentiated commodities into personalized expressions of their owners' social status and aspirations. At the same time, the verses' reference to sociability and leisure suggests the emergence of new patterns of behavior, originating from the commercial boom and resulting relative affluence of the provincial merchant class in the late eighteenth century.

Finally, an afterword by Hedda Reindl-Kiel bookends the volume, providing an Ottomanist perspective on the themes of the issue. Dwelling on the relative neglect of Southeastern European history in recent decades, she points out that the material world of the region throughout the early modern period was much more interconnected than the divergence of modern historiographies have suggested so far. Pointing out the need to fill the gap and reinvigorate the dialogue between national and regional historiographies on the one hand, and recent advances in Ottoman historiography on the other, she sets a research agenda for future inquiries into the world of objects and people in Southeastern Europe during the Ottoman period. 